\title{
Chemical Analysis of Essential Oil and Hydrolates of Leaves, Inflorescences and Stems of Piper chimonanthifolium Kunth
}

\author{
Riani, L. R.; Macedo, A. L.; Chedier, L. M.; Pimenta, D. S. \\ Rev. Virtual Quim., 2017, 9 (4), 1560-1569. Data de publicação na Web: 31 de agosto de 2017 \\ http://rvq.sbq.org.br

\begin{abstract}
Análise Química de Óleos Essenciais e Hidrolatos de Folhas, Inflorescências e Caules de Piper chimonanthifolium Kunth
\end{abstract}

Resumo: Plantas do gênero Piper são frequentemente utilizadas comercialmente. A espécie Piper chimonanthifolium Kunth. apresenta poucos estudos em literatura quanto a sua composição química e atividades biológicas. Óleos essenciais de outras espécies deste gênero apresentam boas atividades biológicas, principalmente contra microrganismos. Este trabalho apresenta uma comparação da composição química de óleos essenciais e hidrolatos de folhas, inflorescências e caules desta espécie. As amostras foram obtidas por co-destilação e analisadas por cromatografia com fase gasosa acoplada à espectrometria de massas (CG-EM). As amostras mostraram presença de monoterpenos e sesquiterpenos, com predominância de monoterpenos. A piperitona, um monoterpeno com atividades biológicas anteriormente relatadas na literatura, foi a substância com maior destaque. Além desta substância, destacaram-se: $L$-linalol, cis- $\beta$-ocimeno, trans- $\beta$-cimeno, 1 -felandreno, $\alpha$-pineno, limoneno e espatulenol. Algumas dessas substâncias podem exibir variação na composição de acordo com fatores ambientais e podem ser agentes de controle biológico, demonstrando importância ecológica. As análises por CG-EM evidenciaram diferenças na composição química entre folhas, inflorescências e caules, além de demonstrarem potencial biológico para esta espécie.

Palavras-chave: Atividade biológica; Óleo essencial; Monoterpeno; Piperaceae; Piperitona.

\begin{abstract}
Plants of the genus Piper are widely used commercially. Piper chimonanthifolium Kunth. is a species with few studies on chemistry and biological activities. Essential oils of other species of this genus show good biological activities, especially against microorganisms. This work presents a comparative analysis of chemical composition of essential oils and hydrolates of leaves, inflorescences and stems of this specie. Samples were obtained by co-distillation and analyzed by gas chromatography-mass spectrometry (GCMS). The samples were composed of monoterpenes and sesquiterpenes, with predominance of monoterpenes. Piperitone, a monoterpene with important biological activities, was the most important substance and in addition to this compound, $L$-linalool, cis- $\beta$-ocimene, trans- $\beta$-ocimene, 1 -phellandrene, $\alpha$-pinene, limonene, and spathulenol stood out. Some of these substances can exhibit a variation in the composition according to environmental factors or may be biological control agents, demonstrating ecological importance. The chemical characterization showed chemical differences between leaves, stems and inflorescences and demonstrated biological potential for this species.
\end{abstract}

Keywords: Biological activities; Essential oil; Monoterpenes; Piperaceae; Piperitone.

* Universidade Federal Fluminense, Instituto de Química, Departamento de Química Orgânica, Campus do Valonguinho, CEP 24020-150, Niterói-RJ, Brazil.

$M$ arthur macedo@id.uff.br

DOI: 10.21577/1984-6835.20170091

Rev. Virtual Quim. |Vol 9| | No. 4| |1560-1569| 


\section{Chemical Analysis of Essential Oil and Hydrolates of Leaves, Inflorescences and Stems of Piper chimonanthifolium Kunth}

\section{Lorena R. Riani, ${ }^{\text {a }}$ Arthur L. Macedo, ${ }^{b}$ Luciana M. Chedier, ${ }^{\text {C Daniel S. }}$ Pimenta ${ }^{\mathrm{c}, *}$}

a Universidade Federal de Juiz de Fora, Faculdade de Farmácia, Departamento Farmacêutico, Rua José Lourenço Kelmer, s/n, Campus Universitário, CEP 36036-900 Juiz de Fora-MG, Brazil.

${ }^{\mathrm{b}}$ Universidade Federal Fluminense, Instituto de Química, Departamento de Química Orgânica, Campus do Valonguinho, CEP 24020-150, Niterói-RJ, Brazil.

${ }^{\mathrm{c}}$ Universidade Federal de Juiz de Fora, Instituto de Ciências Biológicas, Departamento de Botânica, Rua José Lourenço Kelmer, s/n, Campus Universitário, CEP 36036-900 Juiz de ForaMG, Brazil.

* arthur macedo@id.uff.br

\section{Introduction}

\section{Materials and methods}

2.1. Plant material

2.2. Essential oil extraction and obtaining of hydrolates

2.3. Gas chromatography-mass spectrometry

2.4. Identification of the oil and hydrolate substances

\section{Results}

\section{Discussion}

\section{Conclusion}

\section{Introduction}

The Piperaceae family is distributed in tropical and subtropical regions of both hemispheres, and includes about 4,000 species and the genus Piper $L$. has the highest number of species. ${ }^{1}$ This genus is representative in commercial use, with the Indian specie Piper nigrum L. being the most widespread in the world for producing black pepper. ${ }^{2}$ Species of this genus are often used not only in human diets, but also for other purposes, such as a perfumery fixer. They have several uses in folk medicine because their substances have many biological and pharmacological activities. ${ }^{3}$ Piper aduncum L., known as "fake jaborandi", is reported in folk medicine as diuretic, wound healing and antihemorrhagic, ${ }^{4}$ Piper regnellii (Micah) C. DC has antifungal activity ${ }^{5}$ and Piper hispidinervum C. DC. is used in the manufacture of fixative for fragrances and as 
natural insecticides. ${ }^{6}$

Studies of essential oils of Piper are very important, since this genus is characterized by aromatic species and present a great variety of substances, among them terpenoids and arylpropanoids. The essential oil from a sample of $P$. aduncum, a species used in folk medicine for the treatment of respiratory and inflammatory diseases, presented predominance of monoterpenes (1-3). ${ }^{7}$ Piper malacophyllum (C. Presl) C. DC. $(4,5)$, Piper arboreum Aubl. (6-8), Piper dilatatum Rich. $(9,10)$ and Piper hispidum Kunth (2). presented monoterpenes and sesquiterpenes in their essential oils. ${ }^{8}$ These were also the main substances found in study about essential oil of 10 Piperaceae species of the Brazilian Atlantic Forest $(\mathbf{1}, \mathbf{7}, \mathbf{1 0 - 1 4}){ }^{9}$
Several studies in toxicity against bacterial, fungal and protozoal organisms have been done with species of this genus. ${ }^{10} P$. malacophyllum, P. aduncum (15) and Piper tuberculatum Jacq. exhibited high antifungal action, whereas the former species have antiparasitc and good antibacterial activities. ${ }^{8 b, 11}$ A study of the essential oil from Piper solmsianum C.DC. and its major compound, sarisan (16), in mice behavior showed exciting and depressant effects in tested animals. ${ }^{12}$ The essential oil of Piper corcovadensis (Miq.) C.DC. $(\mathbf{1 7}, \mathbf{1 8})$ exhibited a strong oviposition deterrent activity in Aedes aegypti. ${ }^{13}$ The structural formula of the major substances in the essential oils of this species are in Figure 1.

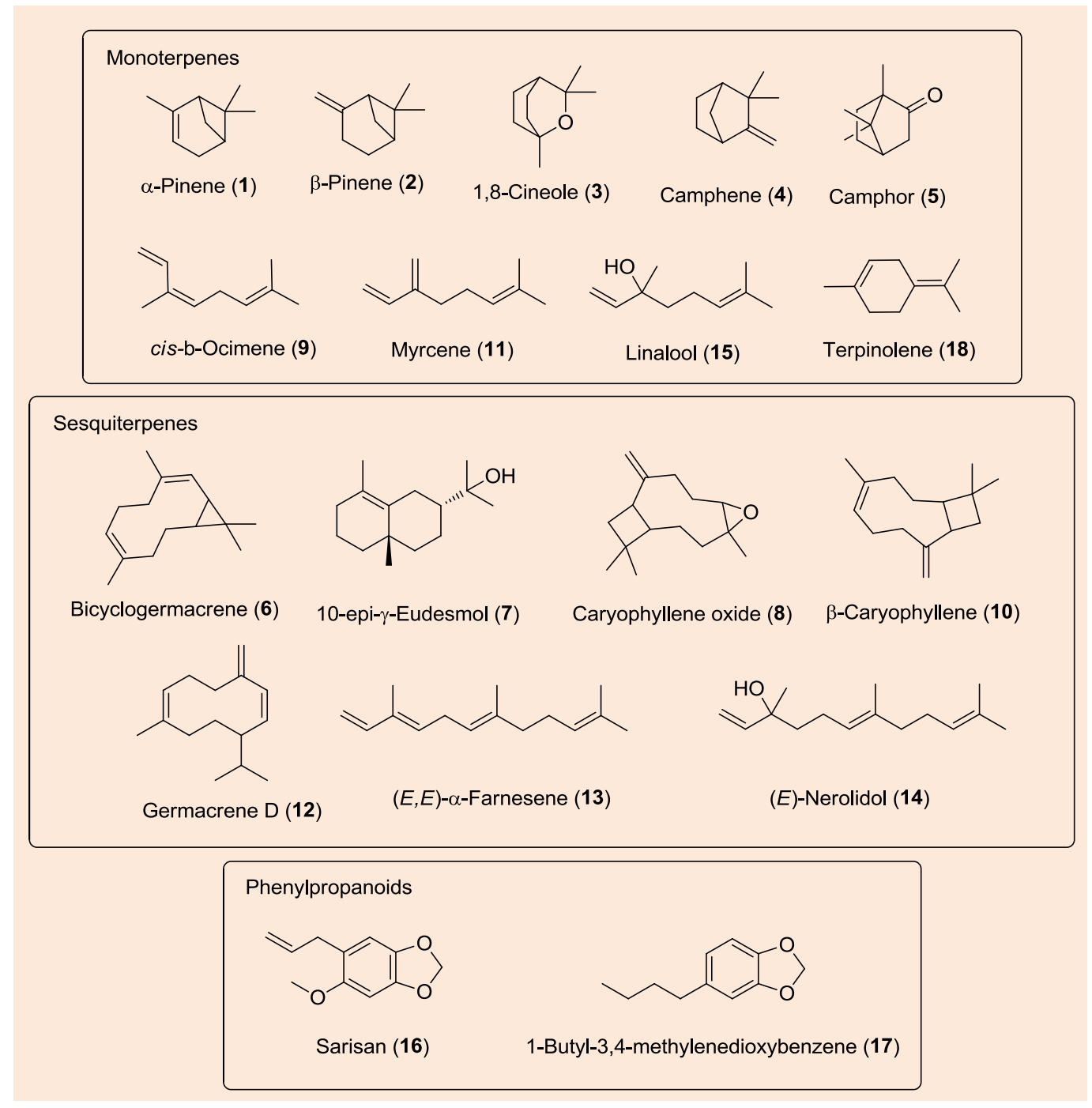

Figure 1. Structural formula of the major substances found in essential oils of Piper spp 
Besides the characterization of essential oils, hydrolates obtained in the extraction may also be pharmacologically tested, so their characterization is also relevant. ${ }^{14}$

Piper chimonanthifolium Kunth. is a shrub, native from Brazil, ${ }^{1}$ and there is a dearth of studies about its biological activities and chemistry. The aim of this study is the chemical characterization of essential oils and hydrolates of leaves, inflorescences and stems of $P$. chimonanthifolium due to the biological relevance of the essential oils of the genus Piper.

\section{Materials and methods}

\subsection{Plant material}

The plant material was collected on the campus of Universidade Federal de Juiz de Fora, Juiz de Fora, Minas Gerais state, Brazil. The plant material was dried in a forced air circulation oven with temperature of $45^{\circ} \mathrm{C}$ until constant weight. The specie was identified by MSc. Danielle Monteiro, from Instituto de Pesquisas Jardim Botânico do Rio de Janeiro. The voucher is found at the Herbarium CESJ, under the register number 57540.

\subsection{Essential oil extraction and obtaining of hydrolates}

An aliquot of $370 \mathrm{~g}$ of leaves was added to a $12 \mathrm{~L}$ flask with $4 \mathrm{~L}$ of distilled water and was subjected to co-distillation using modified Clevenger for $1 \mathrm{~h}$ and $30 \mathrm{~min}$ after boiling. Similarly, aliquots of $130 \mathrm{~g}$ of the inflorescences and stems were added to a $2 \mathrm{~L}$ flask in $1.5 \mathrm{~L}$ of distilled water and were extracted by $1 \mathrm{~h}$ and $30 \mathrm{~min}$. Therefore, six samples were obtained, leaves, inflorescences and stems essential oils and their hydrolates, which were stored at $-18^{\circ} \mathrm{C}$ for later analysis.

\subsection{Gas chromatography-mass spectrometry}

Samples were analyzed in the Plataforma Analítica of Farmanguinhos (FIOCRUZ - Rio de Janeiro state, Brazil), using a HewlettPackard 6890 gas chromatograph equipped with a fused silica capillary column (HP-5, 30 $\mathrm{m} \times 0.25 \mathrm{~mm}, 0.25 \mu \mathrm{m}$ film thickness), helium as carrier gas with a flow rate $1.0 \mathrm{~mL} / \mathrm{min}$; temperature programming from $70^{\circ} \mathrm{C}$ to $290^{\circ} \mathrm{C}\left(2^{\circ} \mathrm{C} / \mathrm{min}\right)$, coupled to a HewlettPackard 5972 mass spectrometer. The MS operating parameters were: $70 \mathrm{eV}$, ion source $250{ }^{\circ} \mathrm{C}$ equipped with El.

2.4. Identification of the oil and hydrolate substances

The compound identifications were carried out by comparison of their retention index (RI) with literature values; and the MS data with those from Wiley 275.1 mass spectral data base besides literature records. $^{15}$

The RI was calculated using a GC data of a homologous series of saturated aliphatic hydrocarbons within $\mathrm{C} 8$ to $\mathrm{C} 30$, performed at the same column and conditions as used in the GC-MS analysis for the essential oils and hydrolates.

\section{Results}

In the analysis of essential oils, 29 substances were identified in leaves (13 monoterpenes and 16 sesquiterpenes) and in inflorescences (14 monoterpenes and 15 sesquiterpenes) and 22 in stem (12 
monoterpenes and 10 sesquiterpenes), representing $88.96 \%$ (65.82\% monoterpenes and $23.14 \%$ sesquiterpenes), $94.02 \%$ (86.78\% monoterpenes and $7.24 \%$ sesquiterpenes) and $98.36 \%$ (73.57\% monoterpenes and $24.79 \%$ sesquiterpenes) of the total chromatogram area, respectively. In the hydrolates, the three substances of leaves and the single substance of stems were identified, totaling $100.00 \%$ of the total chromatogram area, as in inflorescences three substances were identified, representing $96.88 \%$ of the total area. All substances identified in hydrolates are monoterpenes. The structural formula of the major substances are described in Figure 2 and substances found in the samples are described in Table 1.

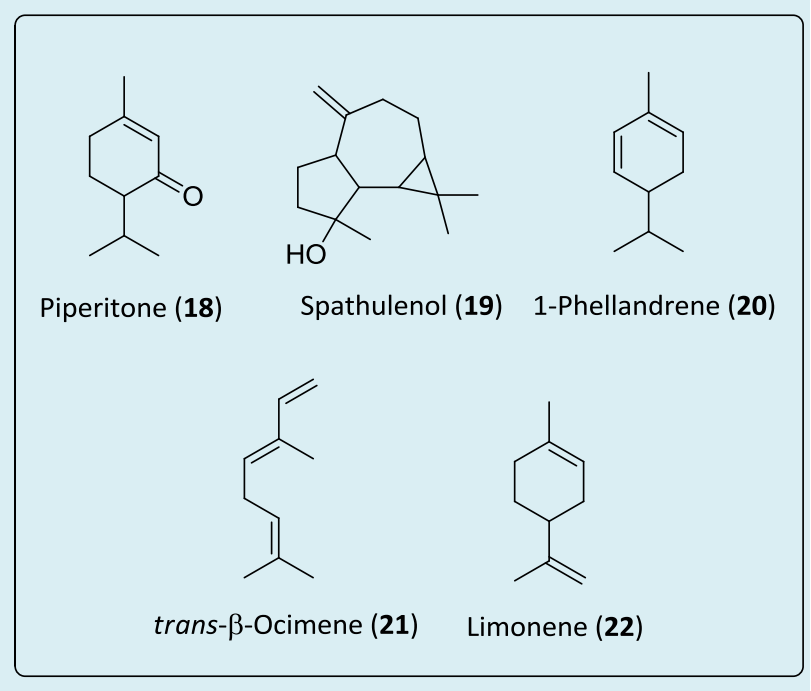

Figure 2. Structural formula of the major substances found in the samples of essential oils and hydrolates of Piper chimonanthifolium Kunth

Table 1. Substances found in essential oils and hydrolates of leaves, inflorescences and stems of Piper chimonanthifolium Kunth.

\begin{tabular}{|c|c|c|c|c|c|c|c|c|c|}
\hline Substances & RT & LOA & LHA & IOA & IHA & SOA & SHA & $\mathrm{RI}$ & CRI \\
\hline Monoterpenes & - & 65.82 & 100.00 & 86.78 & 96.88 & 73.57 & 100.00 & - & - \\
\hline$\alpha$-Pinene & 7.77 & 4.10 & - & 0.90 & - & 6.80 & - & 939 & 934.1 \\
\hline$\beta$-Pinene & 8.99 & 0.80 & - & 0.40 & - & 4.60 & - & 980 & 980.3 \\
\hline$\beta$-Myrcene & 9.18 & 1.31 & - & 0.75 & - & 1.33 & - & 991 & 987.5 \\
\hline 1-Phellandrene & 9.74 & 4.57 & - & 1.30 & - & 3.76 & - & 1005 & 1008.0 \\
\hline$\alpha$-Terpinene & 10.00 & - & - & 1.76 & - & - & - & 1018 & 1017.1 \\
\hline$p$-Cimene & 10.26 & - & - & 4.94 & - & 2.10 & - & 1026 & 1026.1 \\
\hline Limonene & 10.39 & - & - & & - & 7.17 & - & 1031 & 1030.7 \\
\hline cis- $\beta$-Ocimene & 10.48 & 15.70 & - & 7.70 & - & 7.20 & - & 1040 & 1033.8 \\
\hline trans- $\beta$-Ocimene & 10.80 & 0.89 & - & 7.71 & - & 4.20 & - & 1050 & 1044.9 \\
\hline$\gamma$-Terpinene & 11.22 & 0.70 & - & 3.40 & - & 0.90 & - & 1062 & 1059.6 \\
\hline
\end{tabular}




\begin{tabular}{|c|c|c|c|c|c|c|c|c|c|}
\hline Linalool oxide & 11.50 & 0.40 & 10.30 & 0.60 & 11.37 & - & - & 1074 & 1069.3 \\
\hline$\alpha$-Terpinollene & 11.84 & 0.17 & - & 0.95 & - & - & - & 1088 & 1081.2 \\
\hline L-Linalool & 12.37 & 0.20 & - & 31.14 & 25.44 & 2.90 & - & 1098 & 1099.7 \\
\hline cis-Menthenol & 13.18 & 0.57 & 3.10 & - & - & 0.91 & - & 1121 & 1127.6 \\
\hline trans-Menthenol & 13.50 & 1.21 & - & 1.73 & - & - & - & 1140 & 1138.6 \\
\hline Piperitone & 16.97 & 35.20 & 86.60 & 23.50 & 60.07 & 31.70 & 100.00 & 1252 & 1260.4 \\
\hline Sesquiterpenes & - & 23.14 & - & 7.24 & - & 24.79 & - & - & - \\
\hline$\alpha$-Copaene & 20.20 & 0.57 & - & 0.23 & - & - & - & 1376 & 1379.4 \\
\hline trans-Caryophyllene & 21.43 & 2.09 & - & 0.73 & - & 1.62 & - & 1418 & 1426.9 \\
\hline$\alpha$-Humullene & 22.34 & 2.91 & - & 0.78 & - & 2.30 & - & 1454 & 1462.8 \\
\hline ү-Muurollene & 22.72 & 0.68 & - & 0.21 & - & - & - & 1477 & 1477.9 \\
\hline$D$-Germacrene & 22.94 & 0.98 & - & 0.45 & - & - & - & 1480 & 1486.6 \\
\hline$\beta$-Selinene & 23.15 & 1.78 & - & 0.17 & - & - & - & 1485 & 1494.9 \\
\hline$\delta$-Cadinene & 23.81 & 2.10 & - & 0.31 & - & 1.22 & - & 1524 & 1522.1 \\
\hline Cadina-1,4-diene & 24.01 & 0.17 & - & - & - & - & - & 1532 & 1530.4 \\
\hline Calacorene & 24.23 & 0.30 & - & - & - & - & - & 1542 & 1539.6 \\
\hline Nerolidol & 24.75 & 0.80 & - & 2.00 & - & 1.70 & - & 1564 & 1561.2 \\
\hline Spathulenol & 25.30 & 6.60 & - & 0.30 & - & 3.30 & - & 1576 & 1584.2 \\
\hline Caryophyllene oxide & 25.47 & - & - & 0.47 & - & 4.85 & - & 1581 & 1591.2 \\
\hline Humulene epoxide II & 26.11 & 1.60 & - & 0.68 & - & 5.02 & - & 1606 & 1618.9 \\
\hline Cubenol-1,10-di-epi & 26.44 & 0.41 & - & 0.26 & - & 2.17 & - & 1614 & 1633.5 \\
\hline Cubenol-1-epi & 26.62 & 0.48 & - & 0.16 & - & 1.15 & - & 1627 & 1641.4 \\
\hline t-Cadinol & 26.76 & 1.07 & - & 0.23 & - & - & - & 1640 & 1647.6 \\
\hline$\alpha$-Cadinol & 27.09 & 0.60 & - & 0.26 & - & 1.46 & - & 1653 & 1662.1 \\
\hline Total & - & 88.96 & 100.00 & 94.02 & 96.88 & 98.36 & 100.00 & - & - \\
\hline
\end{tabular}

$\mathrm{RT}=$ retention time, $\mathrm{LOA}=$ leaf oil area (\%), LHA = leaf hydrolate area (\%), IOA = inflorescence oil area (\%), IHA = inflorescence hydrolate area (\%), SOA = stem oil area (\%), SHA = stem hydrolate area $(\%), \mathrm{RI}=$ retention index, $\mathrm{CRI}=$ calculated retention index.

\section{Discussion}

Piperitone (18) were found in all samples. This compound, a biologically active monoterpene, has insecticidal activity ${ }^{16}$ and increases the nitrofurantoin activity against Enterobacteria. ${ }^{17}$ This monoterpene is the major compound in all hydrolates and in the essential oils of stem and leaf and the second most abundant substance in the essential oil of inflorescence. The piperitone was not observed in a study of 10 Piperaceae species from the Atlantic Forest. ${ }^{9}$

In addition to 18 , the other prominent substances are cis- $\beta$-ocimene (9), spathulenol 
(19), 1-phellandrene (20) and $\alpha$-pinene (1) in leaf essential oil, $L$-linalool (15), 9 and trans$\beta$-ocimene (21) in the essential oil of inflorescence, $\mathbf{9}$, limonene (22) and $\mathbf{1}$ in the essential oil of stem (Table 1). These substances were also found in the study of Santos and coworkers. ${ }^{9}$

trans- $\beta$-Ocimene (21) is present in great amounts in inflorescence and stem oils. In a study about the variation of the chemical substances of essential oil of Houttuynia cordata Thunb., another Piperales, this monoterpene had significant positive correlation with the altitude. ${ }^{18}$

cis- $\beta$-Ocimene (9) was found in the three essential oils and was the second most abundant compound in the oil of leaf. This compound was found as major substance of $P$. dilatatum oil in a study of three Piper species collected in the region of Distrito Federal, Brazil. ${ }^{8 a}$ In the same study, spathulenol (19) was found in essential oil of three Piper species (P. arboreum, $P$. dilatatum and $P$. hispidum) and this sesquiterpene can be used as a food flavoring and in sophisticated perfumes. ${ }^{19}$ This substance was also found in a study with six species of Achillea L., which reported high level of $\mathbf{1 9}$ with soil development, shown by the accumulation of $\mathrm{CaCO}_{3} .{ }^{20}$ The substance 19 was described as the major compound of essential oil from Scutia buxifolia Reissek and showed interesting antioxidant activity and moderate antimicrobial activity. ${ }^{21}$

$\alpha$-Pinene (1) is a monoterpene found also in $P$. hispidum essential $\mathrm{oil}^{8 \mathrm{a}}$ and other Piperaceae species $^{9}$ and was described as insecticidal repellent ${ }^{22}$ and cytotoxic selectively against tumor cells. ${ }^{23}$ The linalool (15) was the major substance of inflorescences essential oil and was found in high concentration in inflorescence hydrolate but was absent or in low concentrations in the other samples, so may be thought of as a chemical marker for quality control of inflorescences. This compound shows the importance of chemical composition studies of different plant organs. This monoterpene has commercial importance in perfumery and cosmetics $^{24}$ and showed many biological activities such as insecticide, antimicrobial, ${ }^{25}$ anticonvulsive, ${ }^{26}$ sedative, ${ }^{27}$ neuroprotective, ${ }^{28} \quad$ Alzheimer's disease treatment ${ }^{29}$ and protection against cigarret smoke-induced acute lung inflammation. ${ }^{30} \mathrm{~A}$ study about the action of some essential oils against mosquitoes and ticks showed $\mathbf{1}$ and 15 as some of the major substances of essential oil of leaves of Juniperus communis L., and this oil presented activity against two species of tick and mosquito Aedes aegypti (L.). ${ }^{31}$

Limonene (22) is a monoterpene found only in the essential oil of stem that plays a modulatory role in the induction of the brown adipocyte-like phenotype as well as promotion of lipid metabolism. ${ }^{32}$ This compound can be a kairomone, increasing the parasitism of Dastarcus helophoroides in Asian longhorned beetle, acting as an important biological control agent. ${ }^{33}$

\section{Conclusion}

In the analysis of essential oils of leaves, inflorescences and stems of $P$. chimonanthifolium monoterpenes and sesquiterpenes were found, with predominance of monoterpenes, and, in the hydrolates, only monterpenes were found. Chemical differences were found between the analyzed parts of the plant and chemical characterization suggests pharmacological and cosmetic potential.

\section{Acknowledgements}

Plataforma Analítica de Farmanguinhos (FIOCRUZ-RJ) for the GC-MS analysis, MSc. Danielle Monteiro for the identification of the specie, CAPES and CNPq for the scholarships and Programa de Extensão Universitária (ProExt) of Ministério da Educação for the fundings. 


\section{References}

${ }^{1}$ Monteiro, D.; Guimarães, E. F. Flora do Parque Nacional do Itatiaia - Brasil: Manekia e Piper (Piperaceae). Rodriguésia 2009, 60, 999. [Link]

${ }^{2}$ Nunes, J. D.; Torres, G. A.; Davide, L. C.; Salgado, C. C. Citogenética de Piper hispidinervum e Piper aduncum. Pesquisa Agropecuária Brasileira 2007, 42, 1049. [CrossRef]

${ }^{3}$ Scott, I. M.; Jensen, H. R.; Philogène, B. J. R.; Arnason, J. T. A review of Piper spp. (Piperaceae) phytochemistry, insecticidal activity and mode of action. Phytochemistry Reviews 2007, 7, 65. [CrossRef]

${ }^{4}$ Orjala, J.; Erdelmeier, C. A. J.; Wright, A. D.; Rali, T.; Sticher, O. Five new prenylated $p$ hydroxybenzoic acid derivatives with antimicrobial and molluscicidal activity from Piper aduncum leaves. Planta Medica 1993, 59, 546. [CrossRef] [PubMed]

${ }^{5}$ Pessini, G. L.; Dias Filho, B. P.; Nakamura, C. V.; Cortez, D. A. G. Antifungal activity of the extracts and neolignans from Piper regnellii (Miq.) C. DC. var. pallescens (C. DC.) Yunck. Journal of the Brazilian Chemical Society 2005, 16, 1130. [CrossRef]

${ }^{6}$ Fazolin, M.; Estrela, J. L. V.; Catani, V.; Alécio, M. R.; Lima, M. S. d. Propriedade inseticida dos óleos essenciais de Piper hispidinervum C. DC.; Piper aduncum L. e Tanaecium nocturnum (Barb. Rodr.) Bur. \& K. Shum sobre Tenebrio molitor L., 1758. Ciência e Agrotecnologia 2007, 31, 113. [CrossRef]

${ }^{7}$ Oliveira, G. L.; Cardoso, S. K.; Lara Júnior, C. R.; Vieira, T. M.; Guimarães, E. F.; Figueiredo, L. S.; Martins, E. R.; Moreira, D. L.; Kaplan, M. A. C. Chemical study and larvicidal activity against Aedes aegypti of essential oil of Piper aduncum L. (Piperaceae). Anais da Academia Brasileira de Ciências 2013, 85, 1227. [CrossRef] [PubMed]

${ }^{8}$ a) Potzernheim, M. C. L.; Bizzo, H. R.; Vieira, R. F. Análise dos óleos essenciais de três espécies de Piper coletadas na região do
Distrito Federal (Cerrado) e comparação com óleos de plantas procedentes da região de Paraty, RJ (Mata Atlântica). Revista Brasileira de Farmacognosia 2006, 16, 246; [CrossRef] b) Santos, T. G.; Rebelo, R. A.; Dalmarco, E. M.; Guedes, A.; Gasper, A. L. d.; Cruz, A. B.; Schmit, A. P.; Cruz, R. C. B.; Steindel, M.; Nunes, R. K. Composição química e avaliação da atividade antimicrobiana do óleo essencial das folhas de Piper malacophyllum (C. Presl.) C. DC. Química Nova 2012, 35, 477. [CrossRef]

${ }^{9}$ Santos, P. R. D. d.; Moreira, D. d. L.; Guimarães, E. F.; Kaplan, M. A. C. Essential oil analysis of 10 Piperaceae species from the Brazilian Atlantic forest. Phytochemistry 2001, 58, 547. [CrossRef] [PubMed]

${ }^{10}$ a) Carrara, V. D.; de Souza, A.; Dias, B. P.; Nakamura, C. V.; de Paulo, L. F.; Young, M. C. M.; Svidzinski, T. I. E.; Cortez, D. A. G. Chemical composition and antifungal activity of the essential oil from Piper amalago L. . Acta Farmacéutica Bonaerense 2010, 29, 1459; [Link] b) Guerrini, A.; Sacchetti, G.; Rossi, D.; Paganetto, G.; Muzzoli, M.; Andreotti, E.; Tognolini, M.; Maldonado, M. E.; Bruni, R. Bioactivities of Piper aduncum L. and Piper obliquum Ruiz \&amp; Pavon (Piperaceae) essential oils from Eastern Ecuador. Environmental Toxicology and Pharmacology 2009, 27, 39; [CrossRef] [PubMed] c) Marques, A. M.; Barreto, A. L. S.; Batista, E. M.; Curvelo, J. A. D. R.; Velozo, L. S. M.; Moreira, D. D. L.; Guimarães, E. F.; Soares, R. M. A.; Kaplan, M. A. C. Chemistry and biological activity of essential oils from Piper claussenianum (Piperaceae). Natural Products Communication 2010, 5, 1837. [PubMed]

${ }^{11}$ Navickiene, H. M. D.; Morandim, A. d. A.; Alécio, A. C.; Regasini, L. O.; Bergamo, D. C. B.; Telascrea, M.; Cavalheiro, A. J.; Lopes, M. N.; Bolzani, V. d. S.; Furlan, M.; Marques, M. O. M.; Young, M. C. M.; Kato, M. J. Composition and antifungal activity of essential oils from Piper aduncum, Piper arboreum and Piper tuberculatum. Química Nova 2006, 29, 467. [CrossRef] 
${ }^{12}$ Moreira, D. d. L.; Santos, P. O. d.; Pereira, N. A.; Cardoso, G. L.; Guimarães, E. F.; Kaplan, M. A. C. Effect of the essential oil from Piper solmsianum C.DC. leaves in mice Behaviour. Anais da Academia Brasileira de Ciências 2000, 72, 291. [CrossRef] [PubMed]

${ }^{13}$ da Silva, M. F. R.; Bezerra-Silva, P. C.; de Lira, C. S.; de Lima Albuquerque, B. N.; Agra Neto, A. C.; Pontual, E. V.; Maciel, J. R.; Paiva, P. M. G.; Navarro, D. M. d. A. F. Composition and biological activities of the essential oil of Piper corcovadensis (Miq.) C. DC (Piperaceae). Experimental Parasitology 2016, 165, 64. [CrossRef] [PubMed]

${ }^{14}$ Nascimento, E. M.; Furlong, J.; Pimenta, D. S.; Prata, M. C. d. A. Efeito anti-helmíntico do hidrolato de Mentha villosa Huds. (Lamiaceae) em nematóides gastrintestinais de bovinos. Ciência Rural 2009, 39, 817. [CrossRef]

${ }^{15}$ Adams, R. P. Identification of essential oil components by gas chromatography/mass spectrometry, 4a. ed., Allured Publishing Corporation: Carol Stream, 2007.

${ }^{16}$ a) Ketoh, G. K.; Koumaglo, H. K.; Glitho, I. A. Inhibition of Callosobruchus maculatus (F.) (Coleoptera: Bruchidae) development with essential oil extracted from Cymbopogon schoenanthus L. Spreng. (Poaceae), and the wasp Dinarmus basalis (Rondani) (Hymenoptera: Pteromalidae). Journal of Stored Products Research 2005, 41, 363; [CrossRef] b) Wang, C.-F.; Zhang, W.-J.; You, C.-X.; Guo, S.-S.; Geng, Z.-F.; Fan, L.; Du, S.-S.; Deng, Z.-W.; Wang, Y.-Y. Insecticidal constituents of essential oil derived from Zanthoxylum armatum against two storedproduct insects. Journal of Oleo Science 2015, 64, 861. [CrossRef] [PubMed]

${ }^{17}$ Shahverdi, A. R.; Rafii, F.; Tavassoli, F.; Bagheri, M.; Attar, F.; Ghahraman, A. Piperitone from Mentha longifolia var. chorodictya Rech $F$. reduces the nitrofurantoin resistance of strains of enterobacteriaceae. Phytotherapy Research 2004, 18, 911. [CrossRef] [PubMed]

${ }^{18}$ Liu, L.; Wu, W.; Zheng, Y.-L.; Huang, C.-Y.; Liu, R.-J. Variations on the chemical components of the volatile oil of Houttuynia cordata Thunb. populations from different valleys and altitudes of Mt. Emei. Acta Ecologica Sinica 2007, 27, 2239. [Link]

${ }^{19}$ van der Linde, L. M.; Van Lier, F. P.; van der Weerdt, A. J. A.; Naarden International N.V., 1987. (US 4704232)

${ }^{20}$ Rahimmalek, M.; Tabatabaei, B. E. S.; Etemadi, N.; Goli, S. A. H.; Arzani, A.; Zeinali, $H$. Essential oil variation among and within six Achillea species transferred from different ecological regions in Iran to the field conditions. Industrial Crops and Products 2009, 29, 348. [CrossRef]

${ }^{21}$ Boligon, A. A.; Piana, M.; Brum, T. F. D.; Froeder, A. L. F.; Belke, B. V.; Schwanz, T. G.; Mario, D. N.; Alves, S. H.; Athayde, M. L. Scutia buxifolia Reissek essential oil: in vitro antioxidant and antimicrobial activities. Anais da Academia Brasileira de Ciências 2014, 86, 1463. [CrossRef] [PubMed]

${ }^{22}$ Ojimelukwe, P. C.; Adler, C. Potential of zimtaldehyde, 4-allyl-anisol, linalool, terpineol and other phytochemicals for the control of the confused flour beetle (Tribolium confusum Duval) (Col., Tenebrionidae). Journal of Pesticide Science 1999, 72, 81. [Link]

${ }^{23}$ Paduch, R.; Trytek, M.; Król, S. K.; Kud, J.; Frant, M.; Kandefer-Szerszeń, M.; Fiedurek, J. Biological activity of terpene compounds produced by biotechnological methods. Pharmaceutical Biology 2016, 54, 1096. [CrossRef] [PubMed]

${ }^{24}$ Alcântara, J. M.; Yamaguchi, K. K. d. L.; Veiga Junior, V. F. d.; Lima, E. S. Composição química de óleos essenciais de espécies de Aniba e Licaria e suas atividades antioxidante e antiagregante plaquetária. Química Nova 2010, 33, 141. [CrossRef]

${ }^{25}$ Prates, H. T.; Leite, R. C.; Craveiro, A. A.; Oliveira, A. B. Identification of some chemical components of the essential oil from molasses grass (Melinis minutiflora Beauv.) and their activity against cattle-tick (Boophilus microplus). Journal of the Brazilian Chemical Society 1998, 9, 193. [CrossRef] 
${ }^{26}$ Elisabetsky, E.; Silva Brum, L. F.; Souza, D. $O$. Anticonvulsant properties of linalool in glutamate-related seizure models. Phytomedicine 1999, 6, 107. [CrossRef] [PubMed]

${ }^{27}$ Gastón, M. S.; Cid, M. P.; Vázquez, A. M.; Decarlini, M. F.; Demmel, G. I.; Rossi, L. I.; Aimar, M. L.; Salvatierra, N. A. Sedative effect of central administration of Coriandrum sativum essential oil and its major component linalool in neonatal chicks. Pharmaceutical Biology 2016, 1. [CrossRef] [PubMed]

${ }^{28}$ Park, H.; Seol, G. H.; Ryu, S.; Choi, I.-Y. Neuroprotective effects of (-)-linalool against oxygen-glucose deprivation-induced neuronal injury. Archives of Pharmacal Research 2016, 39, 555. [CrossRef]

${ }^{29}$ Sabogal-Guáqueta, A. M.; Osorio, E.; Cardona-Gómez, G. P. Linalool reverses neuropathological and behavioral impairments in old triple transgenic Alzheimer's mice. Neuropharmacology 2016, 102, 111. [CrossRef] [PubMed]
${ }^{30}$ Ma, J.; Xu, H.; Wu, J.; Qu, C.; Sun, F.; Xu, S. Linalool inhibits cigarette smoke-induced lung inflammation by inhibiting NF-KB activation. International Immunopharmacology 2015, 29, 708. [CrossRef] [PubMed]

${ }^{31}$ Carroll, J. F.; Tabanca, N.; Kramer, M.; Elejalde, N. M.; Wedge, D. E.; Bernier, U. R.; Coy, M.; Becnel, J. J.; Demirci, B.; Başer, K. H. C.; Zhang, J.; Zhang, S. Essential oils of Cupressus funebris, Juniperus communis, and J. chinensis (Cupressaceae) as repellents against ticks (Acari: Ixodidae) and mosquitoes (Diptera: Culicidae) and as toxicants against mosquitoes. Journal of Vector Ecology 2011, 36, 258. [CrossRef] [PubMed]

${ }^{32}$ Lone, J.; Yun, J. W. Monoterpene limonene induces brown fat-like phenotype in 3T3-L1 white adipocytes. Life Sciences 2016, 153, 198. [CrossRef] [PubMed]

${ }^{33}$ Wei, J.-R.; Yang, Z.-Q.; Hao, H.-L.; Du, J.-W. $(R)-(+)$-Limonene, kairomone for Dastarcus helophoroides, a natural enemy of longhorned beetles. Agricultural and Forest Entomology 2008, 10, 323. [CrossRef] 